was made under a special appropriation for the International Geophysical Year. The research fields included are astronomy, chemistry, developmental biology, earth sciences, engineering sciences, environmental biology, genetic biology, mathematical sciences, molecular biology, physics, psychobiology, regulatory biology, and systematic biology. A list of the grants, including institution, name of principal scientist, title, duration and amount, can be obtained from the Secretary, National Science Foundation, Washington 25, D.C.

\section{Ulster Folk Museum}

THE Museums Journal of December 1954 announces that the Committee appointed by the Northern Ireland Minister of Finance has recommended in its report that an Ulster Folk Museum be established in the grounds of Belfast Castle at a probable cost of

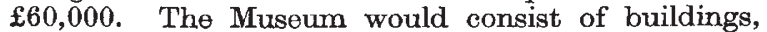
implements and other objects displayed in a natural setting and under living and working conditions. Buildings of a traditional type would be rebuilt or copied and so far as possible put to their original use. The Committee suggests that the Museum should be established on a national basis, with substantial Government financial backing. The Corporation of Belfast has already agreed to make available at a nominal rent some $5 \frac{1}{2}$ acres in the grounds of the Castle.

\section{Leicester Museum and Art Gallery}

THE forty-eighth report of the Committee of the Leicester Museum and Art Gallery records the opening to the public of the herb garden and Deacon Clock workshop in Castle View. The new garden and the reconstruction illustrating one of Leicestershire's oldest industries provide, on the site of what was formerly a builder's yard, an amenity which has transformed this corner of old Leicester. The report is issued in an attractive form, and interesting acquisitions are recorded.

\section{Colonial Service: Recent Appointments}

THE following appointments have recently been made in the Colonial Service: A. L. Job (inspector of mines, Tanganyika), inspector of mines, Uganda ; R. B. J. Deane, tea officer, Agricultural Department, Mauritius; K. G. Windsor, agricultural officer, Northern Region, Nigeria ; B. J. Gee, fisheries officer, Northern Region, Nigeria; R. G. Dixon, assistant conservator of forests, Federation of Malaya; A. W. Gunthert, mineralogist, Federation of Nigeria; A. G. Royle, inspector of mines, Tanganyika; J. A. Armstrong, entomologist, East Africa High Commission; J. B. Davies, entomologist, Sleeping Sickness Service, Northern Region, Nigeria.

\section{Planned Parenthood}

THE fourth International Conference on Planned Parenthood was held at Stockholm during August 17-22, 1953, at the invitation of Riksforbundet for Sexuell Upplysing (National League for Sex Education) and was attended by 158 delegates and observers from twenty-one countries. A report on the proceedings has now been published and includes papers on such topics as world population trends and their relation to food supplies, current experiments in birth control, termination of pregnancies, sterilization, subfertility, sterility, artificial insemination, marriage counselling and sex education. Great Britain was represented on the organizing committee by Mrs.
Margaret Pyke and Dr. Helena Wright on behalf of the Family Planning Association. This interesting and informative report may be obtained from the International Planned Parenthood Federation, 69 Eccleston Square, London, S.W.1, price 10s. $6 d$.

\section{Symposium on Condensation Nuclei}

A SYMPOSIUM on atmospheric condensation nuclei will be held in the School of Cosmic Physics of the Dublin Institute for Advanced Studies, 5 Merrion Square, Dublin, during April 26-28. Papers may be read and contributions to the discussions made in English, French, German or Italian; interpreters will be provided during the session. Papers from France; Great Britain, Ireland, Italy, Sweden, Switzerland, the United States and West Germany have already been promised. Notification of attendance must reach Prof. L. W. Pollak, at the Dublin Institute for Advanced Studies, before April 10.

\section{Announcements}

H.R.H. The DUKe of Edinburgh has been elected an honorary member of the Institution of Electrical Engineers.

Dr. J. N. Hunt, senior lecturer in Guy's Hospital Medical School, has been appointed to the University of London readership in physiology tenable at that School.

Mr. Cecr Warburton, entomologist, formerly of the School of Agriculture and the Molteno Institute, University of Cambridge, who celebrated his hundredth birthday last year (see Nature, February 13, 1954, p. 289), was one hundred and one on February 6.

THE fourth World Petroleum Congress will be held in Rome during June 6-15. Further information can be obtained from the General Secretariat, Via Tevere 20, Rome.

Av International Symposium on Electrical Discharges in Gases will be held in the Technical University, Delft, during April 25-30. Further information can be obtained from $\mathrm{A}$. W. van Wagensveld, Mijnbouwplein 11, Delft, Netherlands.

AN international conference on "Non-destructive Testing of Materials" will be held in Brussels during May 23-28. Further information can be obtained from the Secretary, l'Association des Industriels de Belgique, 29 Avenue André-Drouart, Auderghem, Brussels.

THE sixteenth General Assembly of the Fédération Internationale Pharmaceutique will be held in London during September 19-23. Further information can be obtained from D. F. Lewis, Pharmaceutical Society of Great Britain, 17 Bloomsbury Square, London, W.C.1.

A sUMMER school in programme design for automatic digital computing machines will be held in the University Mathematical Laboratory at Cambridge during September 12-23. Further information can be obtained from G. F. Hickson, secretary of the Board of Extra-mural Studies, Stuart House, Cambridge.

As already announced, the Fourteenth International Congress of Pure and Applied Chemistry is being held in Zurich during July 21-27. Registration for attendance must close on February 15. Correspondence should be sent to the SecretaryGeneral, XIVth International Congress of Pure and Applied Chemistry, Zurich 1. 